\title{
LANDASAN FILOSOFIS PEMIKIRAN TASAWUF ABDURRAUF SINGKEL TENTANG ALLAH, MANUSIA, DAN ALAM
}

\author{
Ahmad Rivauzi \\ Universitas Negeri Padang \\ e-mail: ahmadrivauzi@fis.unp.ac.id
}

\begin{abstract}
Abdurrauf Singkel (d. 1105 H / 1693 AD), was one of the great scholars of the 17th century and he was a key figure in the development of Islam, especially in the field of Sufism,it was as one of the forms of education in the aspect of mankind in the archipelago. Almost all of the Shațariyyah lineage is centered on itself and through some of his students, this congregation is spread to various regions of the Malay-Nusantara world. Through the research with a hermeneutic approach to his works, this paper aims to reveal the philosophical foundation of the Abdurrauf Singkel thought about Sufism that puts the Quran and Hadith as the basis and normative source of it. The affirmation and reinforcement of tauhid, its reinterpretation to the concept of wahdāt al-wujüd which places man as the shadow of Allah, the concept of the creation of nature through the process of emanation and awakening the consciousness of servanthood through the effort of dying (ikhtiyari) by fana in zikrullah as the way of recognizing the nature of being and ma'rifatullahh, is the philosophical foundation of the Sufism thought which he developed in the Shațāriyyah.
\end{abstract}

\begin{abstract}
Abstrak: Abdurrauf Singkel (w. 1105 H/1693 M), adalah salah seorang ulama besar pada abad ke-17 dan merupakan tokoh kunci dalam perkembangan Islam terutama pada bidang tasawuf sebagai salah satu bentuk pendidikan pada aspek keruhanian di Nusantara. Hampir semua silsilah tarekat Shațāriyyah berpusat kepada dirinya dan melalui sejumlah muridnya, tarekat ini tersebar ke berbagai wilayah di dunia Melayu-Nusantara. Melalui penelitan dengan pendekatan hermeneutik terhadap karya-karyanya, tulisan ini bertujuan untuk mengungkapkan landasan filosofis pemikiran tasawuf Abdurrauf Singkel yang menempatkan al-Qur'an dan Hadis sebagai dasar dan sumber normatif dari pemikiran tasawufnya. Penelitian menemukan bahwa penegasan dan penguatan tauhid, reinterpretasinya terhadap konsep waḥdāt al-wujūd yang menempatkan manusia sebagai bayangan dari Allah, konsep penciptaan alam melalui proses pemancaran (emanasi) serta membangun kesadaran kehambaan melalui upaya mati ikhtiyari dengan cara fana dalam dzikrullah sebagai jalan untuk mengenali hakikat wujud dan ma'rifatullāh, merupakan pondasi filosofis dari bangunan pemikiran tasawuf yang dikembangkannya dalam tarekat Shațāriyyah.
\end{abstract}

Keywords: philosophical foundation; sufism; Abdurrauf Singkel 


\section{A. Pendahuluan}

Menurut Ismail Raji al-Faruqi, kehancuran dan kemunduran Islam disebabkan oleh karena kesemrautan wajah pendidikan di dunia Islam. Inti kehancuran masyarakat muslim sekarang ini dipandang bersumber pada hancurnya sistem pendidikan yang dicangkok secara membabi buta dari Barat. Anakanak muslim terasingkan dari nilai-nilai dan warisan budaya Islam, hubungan mereka dengan sejarah masa lampaunya rusak sehingga tertanam keraguaraguan dan ketidakpercayaan diri pada kebenaran nilai-nilai Islam. ${ }^{1}$

Dalam perspektif Islam, perkembangan pribadi dan masyarakat tidak dilihat dari konteks intelektual dan capaian aspek material semata, akan tetapi harus dilihat dalam konteks hubungan manusia dengan Tuhannya. Pendidikan merupakan media untuk mempersiapkan kematangan dan perkembangan kepribadian manusia yang eksistensinya merupakan hamba sekaligus khalifah Allah di permukaan bumi. Pendidikan yang baik adalah pendidikan yang mampu membantu manusia dalam mewujudkan hubungan yang baik dan dekat dengan Allah. ${ }^{2}$

Berangkat dari realitas tersebut, dibutuhkan dasar-dasar normatif dan filosofis yang sesuai dengan kebutuhan pendidikan Islam untuk mewujudkan kualitas insān kāmil sebagaimana yang dicita-citakan Islam. Dalam konteks ini, kajian pemikiran ulama yang memiliki rekam jejak dan karya-karya di bidang pemikiran ke-Islaman menjadi sangat penting dilakukan. Abdurrauf Singkel adalah salah seorang yang representatif untuk dikaji dan ditelaah pemikiran serta karya-karyanya.

Tulisan ini dimaksudkan untuk mengungkap dan menjelaskan landasan filosofis pemikiran tasawuf Abdurrauf Singkel tentang Allah, manusia, dan alam yang dengan sendirinya menjadi landasan dari aktifitas kehidupan keagamaannya, keilmuannya dan dunia pendidikan ruhani yang digelutinya.

Data primer dalam penelitian ini adalah naskah-naskah salinan karya Abdurrauf Singkel. Di antaranya kitab "Tanbīh al-Māshï" kode 'Ms.A' dan teks h. $11-12$

${ }^{1}$ Ismail Raji al-Faruqi, Islamisasi Pengetahuan, terj: Anas Wahyudin (Bandung: Pustaka, 1982),

${ }^{2}$ Ahmad Rivauzi, "Pemikiran Abdurrauf Singkel tentang Pendidikan dan Implikasinya pada Pondok Pesantren Nurul Yaqin Ringan-Ringan Pakandangan Padang Pariaman”, Disertasi (Padang: PPs IAIN Imam Bonjol Padang, 2014), h.1. 
Tanbīh al-Māshi hasil penelitian filologi Oman Fathurrahman dengan kode 'Ms.B'. Bahan kajian lainnya adalah teks Bayān Tajalli, Lubb al-Kashf wa l-Bayān limā Yarāhu'l-Muhtazar bi'l-I'yān (Penjelasan mengenai hal-hal yang dilihat oleh si mati dalam sakaratnya), ${ }^{3}$ Kifāyah al-Muhtājīn ilā Mashrab al-Muwaḥhidīn alQāilīn bi Waḥdah al-Wujūd (Bekal Bagi Orang yang Membutuhkan Minuman Ahli Tauhid Penganut Wahdatul Wujud, bahasa Melayu),Umdah al-Muhtājīn ilā Sulūk Maslak al-Mufarridīn (Pijakan bagi orang-orang yang menempuh jalan Tasawuf, bahasa Melayu), dan teks Daqāiq al-Hurūf (Kedalaman Makna Huruf, bahasa Melayu). ${ }^{4}$

Penelitian ini merupakan penelitian kepustakaan (library research), dan termasuk kategori penelitian kualitatif karena terdapatnya kepentingan terhadap penafsiran dan mencari makna dari teks-teks tertulis, ${ }^{5}$ pada sumbersumber kepustakaan. ${ }^{6}$ Pendekatan yang digunakan adalah pendekatan hermeneutic dengan tiga pusaran yang dijadikan starting point dan point of view, yaitu world of the text (aspek kebahasaan), the world of the author (dunia penulis teks), dan the world of the reader (dunia pembaca teks). ${ }^{7}$

\section{B. Riwayat Singkat Abdurrauf Singkel}

Nama lengkap Abdurrauf Singkel adalah "Abd ar-Ra'uf bin al-Jāwiyy alFansūriyy al-Sinkïliyy, selanjutnya disebut Abdurrauf Singkel. Ia adalah seorang Melayu dari pantai barat laut Aceh, tepatnya di Fansur, (Singkel). Ayahnya adalah seorang Arab yang bernama Syekh Ali. Menurut Rinkes, Abdurrauf dilahirkan diperkirakan sekitar tahun 1615.8 Abdurrauf diperkirakan berangkat ke

3Tentang Bayān Tajalli dan Lubb al-Kasyf wal-Bayan limā Yarāhu'l-Muhtazar bi'l-I'yān dalam bentuk transliterasi dapat dijumpai dalam tulisan P. Voorhoeve, Bayān Tajalli; Bahan-bahan untuk Mengadakan Penyelidikan Lebih Mendalam tentang Abdurrauf Singkel. Alih Bahasa: Aboe Bakar, Banda Aceh: Pusat Dokumentasi dan Informasi Aceh, 1980.

4Teks-teks naskah ini penulis peroleh dari Pramono dkk dari Universitas Andalas (Unand) berupa teks buku dan sebagian besar dalam bentuk mikrofilm.

${ }^{5}$ Bagong Suyanto dan Sutinah, Metode Penelitian Sosial; Berbagai Alternatif Pendekatan (Jakarta: Kencana, 2005), h. 186

${ }^{6}$ Sutrisno Hadi, Metodologi Research (Yokyakarta: Rake Sarasin, t.th.), h.19.

${ }^{7}$ Komaruddin Hidayat, Memahami Bahasa Agama: Sebuah Kajian Hermeneutika (Jakarta: Paramadina, 1996), h. 125-126.

${ }^{8}$ Liaw Yock Fang, Sejarah Kesusastraan Melayu Klasik (Singapura: Pustaka Nasional PTE LTD, 1982), h. 197. Data ini juga dapat ditemui dalam, A.H. Johns, The Gift Addressed to the Spiritof the Prophet (Canberra: Published by Australian National University, 1965), h. 11. 
tanah Arab untuk menuntut ilmu pada usia 27 tahun, tinggal di tanah Arab selama 19 tahun kembali ke Nusantara dari tanah Arab diperkirakan dalam usia 46 tahun. Dalam perkembangannya, perhitungan Rinkes ini dijadikan pegangan oleh para ahli. ${ }^{9}$

Berdasarkan catatan dalam salah satu karyanya, 'Umdat al-Muhtājīn ilā Sulūk Maslak al-Mufridīn', Abdurrauf menuliskan 19 orang guru yang dari mereka dia mempelajari berbagai cabang disiplin ilmu Islam, dan 27 ulama lainnya. Abdurrauf belajar di sejumlah tempat, yang tersebar sepanjang rute perjalanan haji, dari Dhuha (Doha) di wilayah Teluk Persia, Yaman, Jeddah, dan akhirnya Makkah dan Madinah. Tahap terakhir dari perjalanannya ia belajar agama terutama tașawwuf kepada dua orang tokoh sufi besar di Madinah yang memegang posisi penting dalam jaringan ulama di dunia Islam. Dua ulama besar tersebut adalah Syaikh Shafiuddin Ahmad al-Dajjani al-Qusyasyi ( \pm 1583-1660 M), seorang ulama besar Makkah. Sepeninggal al-Qusyasyi, Abdurrauf belajar selama satu tahun kepada murid al-Qusyasyi yaitu Syaikh Ibrahim al-Kurani (1616-1689 M) seorang ulama besar asal Madinah. ${ }^{10}$

Abdurrauf pulang ke Aceh pada tahun 1661 M., satu tahun setelah alQusyasyi meninggal. ${ }^{11}$ Pandangan-pandangannya segera mendapat tempat dan merebut hati Sultanah Safiyyatuddin, yang sedang memerintah Aceh, dan mengangkatnya sebagai $Q \bar{a}$ ḍi Mālik al-'Ādil, atau mufti yang bertanggung jawab atas administrasi masalah keagamaan. ${ }^{12}$ Abdurrauf wafat pada tahun 1105 H/1693 M, diperkirakan dalam usia 78 tahun dan dimakamkan di samping makam Teungku Anjong dekat Kuala Sungai Aceh. Inilah sebabnya Abdurrauf dikenal juga dengan sebutan Teungku di Kuala. ${ }^{13}$

${ }^{9}$ Oman Fathurrahman, Tanbīh al-Māshī; Menyoal Wahdatul Wujud, Kasus Abdurrahman Singkel di Aceh Abad 17 (Jakaerta: Mizan, 1999) Cet.I, h. 25, Baca juga: Ahmad Rivauzi, Pendidikan Berbasis Spiritual; Pemikiran Pendidikan Abdurrauf Singkel dalam Kitab Tanbih al-Masyi (Padang: Jasa Surya, 2013.

${ }^{10}$ Azyumardi Azra, Jaringan Ulama Timur Tengah dan Kepulauan Nusantara Abad XVII dan XVIII (Bandung: Mizan, 1994), h. 189 h. 191-193.

11D.A. Rinkes, Abdoeraoef van Singkel' Bijdrage tot de kennis van de mystiek op Sumatra en Java (Heerenven: Hepkema, 1909), h.25, Hurgronje ( Jilid II, 1997), h. 14, dan P. Voorhoeve , Bajan Tadjalli: Gegevens voor een Nadere Studie over Abdurrauf van Singkel, TBG 85; terj: Aboe Bakar (1952), h. 87.

${ }^{12}$ Oman Fathurrahman, Tanbīh al-Māshī..., h. 28.

13 Ibid. 
Abdurrauf Singkel di Aceh memiliki peran yang sangat besar dan merupakan figur utama dalam pendidikan di Nusantara pada masanya karena hampir semua silsilah tarekat Shațāriyyah ${ }^{14}$ berpusat kepada dirinya. ${ }^{15}$ Walaupun ditemukan silsilah tarekat Shațāriyyah di Jawa yang langsung menyebut berasal dari Ahmad al-Qusyasyi (w. 1071 H/1660 M), namun dipandang oleh Azyumardi bahwa Abdurrauf tetap memainkan peran dalam menginisiasi dan memperkenalkan mereka kepada al-Qusyasyi. ${ }^{16}$

Abdurrauf dengan tarekat Shațāriyyah-nya memiliki warisan intelektual, dan kekayaan nilai-nilai pendidikan yang bersifat spiritual yang banyak tersimpan pada lembaran-lembaran naskah karyanya

\section{Landasan Pemikiran Tasawuf Abdurrauf Singkel}

Tasawuf sebagai pendidikan keruhanian harus memiliki dasar yang melandasi pemikiran dan seluruh aktivitasnya. Menurut Achmadi, dasar berfikir menyangkut masalah ideal dan fundamental sehingga pandangan hidup yang melandasi pemikiran dan pendidikan tersebut menjadi kokoh dan komprehensif, serta tidak goyah. ${ }^{17}$

\section{Al-Qur'an dan Hadis sebagai Dasar Pemikiran Tasawuf}

Achmadi menjelaskan sebagaimana dikutip Nata, pandangan hidup seorang Muslim adalah al-Qur'an dan Hadis, maka dasar dari pendidikan di dalam Islam adalah al-Qur'an dan Hadis. Dua sumber dan dasar ini diyakini mengandung

\footnotetext{
${ }^{14}$ Nama tarekat Shațāriyyah dihubungkan kepada Syekh 'Abd Allah al-Shațār (w. 890 H/1485 M), seorang ulama yang masih memiliki hubungan kekeluargaan dengan Syihab al-Dīn Suhrawardi (539-632 H/1145-1234 M), ulama sufi yang mempopulerkan tarekat Suhrawardiyyah dan merupakan salah seorang tokoh Tashawwuf amali pendiri tarekat al-Suhrāwardiyyah. Baca: Abu alWafa' al-Ghanimi Taftazani, Sufi dari Zaman ke Zaman (Madkhal ilā al-Tașawwuf al-Islāmi), terj. Ahmad Rofi Usmani (Bandung: Pustaka, 1985), h. 238, lihat juga: Harun Nasution dkk. Ensiklopedi Islam Indonesia (Jakarta: Djambatan, 1992), h. 868-869; dan Ilma Nugrahani Ismael, 'Awārif alMa'ārif: Sebauah Buku Daras Klasik Tashawwuf( Jakarta: Pustaka Hidayah, 1998).

${ }^{15}$ Oman Fathurrahman, Tarekat Shațāriyyah di Minangkabau (Jakarta: PPIM UIN Jakarta, 2008), h. 32. Selain tarekat Shațāriyah, Abdurrauf juga menganut tarekat Qādiriyah, Kubrāwiyyah, Suhrāwardiyyah, Naqshābandiyah dll. Lihat M. Shagir Abdullah, Khasanah Karya Pusaka Asia Tenggara (Kuala Lumpur: Khazanah Fathaniyah, Jilid I, 1991), h. 131.

${ }^{16}$ Azyumardi Azra, Jaringan Ulama..., h. 198.

${ }^{17}$ Achmadi, Ideologi Pendidikan Islam Paradigma Humanisme Teosentris (Yogyakarta: Pustaka Pelajar, 2005), h. 81.
} 
kebenaran mutlak yang bersifat transendental, universal, dan eternal (abadi), sehingga secara akidah diyakini akan selalu sesuai dengan fitrah manusia dan akan selalu memenuhi kebutuhan manusia kapan saja dan dimana saja. ${ }^{18}$

Al-Qur'an dan Hadis sebagai dasar pendidikan melahirkan nilai-nilai dasar yang dapat diklasifikasikan kepada nilai dasar intrinsik dan nilai dasar instrumental. Nilai intrinsik adalah nilai yang ada dengan sendirinya, bukan prasarat atau alat bagi nilai yang lainnya. Nilai intrinsik, fundamental, dan menempati posisi paling tinggi adalah tauhid. Sedangkan kesungguhan dalam ibadah, shabar, syukur dan lain sebagainya adalah nilai intrumental untuk mencapai tauhid. Dengan dasar tauhid, seluruh kegiatan pendidikan di dalam Islam dijiwai oleh norma-norma ilahiyah dan sekaligus dimotivasi sebagai ibadah. Dengan ibadah, aktivitas pendidikan menjadi lebih bermakna, tidak hannya makna material tetapi juga makna spiritual. Dari dasar tauhid ini muncul dasar-dasar pendidikan lainnya yaitu humanisme (manusiwi), kesatuan umat manusia, keseimbangan, dan rahmat bagi semesta alam. ${ }^{19}$

Abdurrauf menegaskan bahwa sangat penting berpedoman kepada alQur'an dan Hadis Nabi sehingga pengetahuan seseorang akan terpelihara dari kesesatan. Abdurrauf mengutip hadis ${ }^{20}$

Maka pahamilah itu dan berpegang teguhlah kepada al-Qur'an dan Sunnah Rasulullah yang mulia, niscaya engkau dapat petunjuk dan tetap berada pada jalan yang lurus. Nabi Muhammad tidak berkata berdasarkan hawa nafsunya, beliau bersabda: "Aku tinggal dua perkara bagimu, yaitu kitab Allah dan Sunnahku, maka, jelaskanlah al-Qur'an dengan Sunnahku, karena matamu tidak akan buta, kakimu tidak akan terpeleset, dan tanganmu tidak akan putus selama kamu berpegang teguh pada keduanya. ${ }^{21}$

Kesetiaan dan komitmen Abdurrauf untuk senantiasa menjadikan dalil-dali dalam al-Qur'an dan Hadis sebagai dasar dan sumber pemikiran tasawufnya,

${ }^{18}$ Abuddin Nata, Pendidikan dalam Perspektif al-Qur'an (Jakarta: UIN Jakarta Press, 2005), h. 50

${ }^{19}$ Ibid., h. 50-53.

${ }^{20}$ Hadis yang dikutip Abdurrauf di atas adalah dari Abi Nu'im. Baca: Ibrāhīm bin 'Umar bin Hasan al-Ribāth bin 'Alī bin Abī Bakar al-Biqāî̄ (w 885 H), Mașā’id al-Nazari li al-Ashrāf 'ala Maqāṣidi al-Siwari (Riyadh: Maktabah al-Ma'arif, 1987 M/1408 H). Baca: Ahmad Rivauzi, "Pemikiran Abdurrauf Singkel ...", 2014.

${ }^{21}$ Abdurruaf Singkel, Tanbīh al-Māshī.., Ms.B. h. 7, Ms.A. h. 8. 
merupakan landasan utama secara normatif bagi Abdurrauf Singkel dalam membangun pemikiran tasawufnya. Hal ini dapat terlihat pada konsep dan pemahamannya tentang tauhid dan membincang hal-hal ontologis lainnya, misalnya pemahamannya tentang hakikat wujud, eksistensi Allah, hubungan ontologis antara Allah dan manusia, serta alam.

\section{Doktrin Waḥdāt al-Wujūd}

Waḥdāt al-wujūd adalah ungkapan yang terdiri dari dua kata yaitu waḥdāt dan al-wujūd. Waḥdāt artinya sendiri, tunggal atau kesatuan sedang al-wujūd artinya ada. ${ }^{22}$ Dengan demikian wahdāt al-wujūd berarti kesatuan wujud. Konsep waḥdāt al-wujūd dianggap berasal dari seorang tokoh sufi Ibn 'Arabi. Nama lengkapnya Muhammad bin Ali bin ahmad bin Abdullah ath-Tha'i al-Haitami. Lahir pada 27 Ramadhan 560 H (17 Agustus 1165 M) di Murcia, Andalusia tengah, Spanyol. Istilah ini dipandang bukan berasal dari Ibn 'Arabi sendiri melainkan berasal dari Ibn Taymiyah tokoh yang paling keras dalam mengecam dan mengkritik ajaran tersebut. Ibnu Taimiyah telah berjasa dalam mempopulerkan sebutan waḥdātal-wujud ke dalam masyarakat Islam. ${ }^{23}$

Dalam keadaan fāna, waḥdāt al-wujūd ini dapat dipahami dan terlihat dalam ungkapan "wajah sebenarnya satu tetapi jika engkau perbanyak cermin ia menjadi banyak". ${ }^{24}$ Abdurrauf Singkel menjelaskan dalam Kifäyah al-Muhtājīn bahwa ketika Allah menjadikan alam ini, Dia melihat diri-Nya dalam diri-Nya. Penjelasan ini menunjukkan bahwa Allah melihat eksistensi-Nya melalui diriNya, Dia ciptakan alam sebagai tempat tajalli-Nya, dan diciptakan-Nya Adam (pen. citra kemanusian) sebagai kerangka cermin, atau laksana tubuh tanpa nyawa, sehingga asma' Allah dan sifat-Nya adalah ruh dari tubuh itu. Abdurrauf menjelaskan tentang unsur penciptaan manusia, yang dinamakan a'yān khārijiyyah dan ada a'yān thabitah. A'yān khārijizah adalah penampakan luar atau tubuh kasar atau disebut juga wujud alam, sedangkan a'yān thābitah adalah tubuh yang halus (sesuatu yang tetap dalam ilmu Allah). A'yān khärijiyah adalah bayangan dari a'yān thābitah, dan a'yān thābitah adalah bayangan dari zat Allah. Dengan demikian, bayang-bayang bukanlah yang punya bayang-bayang namun

\footnotetext{
22 Mahmud Yunus, Kamus Arab Indonesia, (Jakarta: Hidakarya agung, 1990), h. 492 dan 494.

${ }^{23}$ Rosihan Anwar, Ilmu Tashawwuf(Bandung, Pustaka Setia. 2000), h. 145.

${ }^{24}$ Harun Nasution, Falsafah dan Mistisisme dalam Islam (Jakarta: Bulan Bintang, 1993), h. 93.
}

JURNAL THEOLOGIA — Volume 28, Nomor 2, Desember 2017 
juga bukan sesuatu yang lain dari pada yang punya bayang-bayang. Bayangbayang bukanlah sesuatu yang wujud dengan sendirinya. Inilah yang dimaksudkan oleh Abdurrauf Singkel dengan kesatuan wujud atau wah̆dāt al-wujūd itu. ${ }^{25}$

Analogi lainnya adalah laksana tangan dan geraknya. Gerak bukanlah tangan namun bukan sesuatu yang lain darinya. Melalui paparan analogi tangan dan gerak tangan di atas, Abdurrauf ingin menegaskan bahwa gerak tangan dan tangan tidak lain, tetapi gerak tangan dan tangan tentunya berbeda, gerak adalah gerak, dan tangan adalah tangan. Sama juga halnya dengan perumpamaan si Zaid dengan ilmu yang dimilikinya. ${ }^{26}$

Abdurrauf menegaskan bahwa alam tetap alam, dan khāliq tetap khāliq seperti kutipan di bawah ini:

$$
\text { العبد عبد وإن ترقي والرب رب وإن تنزل }
$$

"yang hamba itu hamba jua jikalau ada ia taraqi yakni naik sekalipun dan yang Tuhan itu Tuhan jua dan jikalagi ada ia tanāzul yakni turun sekalipun."27 (hamba tetap berstatus hamba walaupun taraqi (kesadaran ruhani yang naik atau mendaki medekati Tuhan), dan Tuhan itu tetap Tuhan walaupun tanāzul (turunnya rahmat Allah sebagai respon terhadap mujāhadah dan cinta hamba).

Wujud itu hanya satu yaitu Zat Allah, sedangkan yang lainnya hanya bayang-bayang atau bayangan dari bayang-bayang Allah. Abdurrauf menulis, bahwa ketika alam semesta ini diciptakan oleh Allah, maka alam semesta tersebut tidak boleh dikatakan sebagai 'ain al-Haqq (Allah). Alam semesta ini tidak dapat mewujud dengan sendirinya, tetapi bergantung kepada wujud Allah. Segala sesuatu yang tidak wujud dengan sendirinya, tetapi bergantung kepada wujud lainnya, maka pada hakikatnya wujud sesuatu itu merupakan milik dari wujud lainnya itu, dan tidak ada yang maujūd itu pada hakikatnya selain dari pada Allah. Sebab ketika dikaji hakikat wujud alam semesta ini, maka kita akan sampai kepada kesimpulan akan ketiadaan wujudnya. Inilah puncak dari pemahaman tauhid yang dituntut oleh Allah. ${ }^{28}$

\footnotetext{
${ }^{25}$ Abdurrauf Singkel, Kifāyah al-Muhtājīn, h. 2-4..

26Ibid., h. 4-5.

27 Ibid., h. 5.

${ }^{28}$ Ibid., h. 6.
} 
Pada manusia ada unsur lahir dan batin, dan pada Tuhan pun ada unsur lahir dan batin. Unsur lahir manusia adalah fisiknya, sedangkan batinnya adalah roh atau jiwa yang hal ini merupakan pancaran, bayangan Tuhan. Kemudian unsur lahir pada Tuhan adalah sifat-sifat ketuhanannya yang tampak di alam ini dan unsur batinnya adalah dzat Tuhan. Bersatunya unsur lahut yang ada pada manusia dengan unsur nasut yang ada pada Tuhan itulah yang dinamakan insan kamil. Proses bersatunya itu yang dinamakan dengan fāna atau tenggelam dalam dzikrullah.29

Di antara ayat al-Qur'an yang memberikan petunjuk bahwa Tuhan memiliki unsur lahir dan batin adalah:

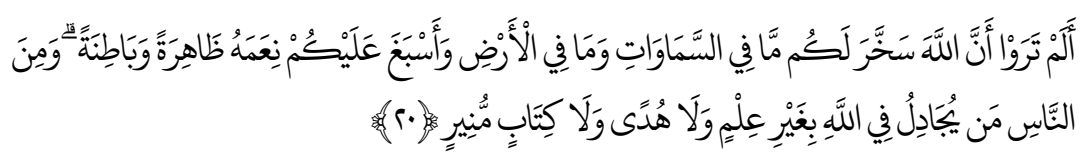

"Tidakkah kamu perhatikan sesungguhnya Allah telah menundukkan untuk (kepentingan) mu apa yang di langit dan apa yang di bumi dan menyempurnakan untukmu ni'mat-Nya lahir dan batin. Dan di antara manusia ada yang membantah tentang (keesaan) Allah tanpa ilmu pengetahuan atau petunjuk dan tanpa Kitab yang memberi penerangan. Dengan menyempurnakan untukmu niatnya lahir dan batin." 30

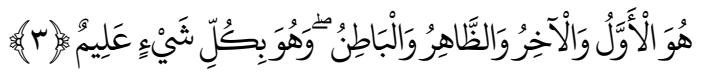

“Dialah Yang Awal dan Yang Akhir, Yang Zãhir dan Yang Bãtin; dan Dia Maha Mengetahui segala sesuatu." 31

Kata al-awwal diartikan yang telah ada sebelum sesuatu yang ada. Al-Ākhir artinya yang nyata adanya karena banyak bukti-buktinya dan yang batin adalah yang tidak dapat digambarkan hakikat dzatnya oleh akal. Namun menurut para sufi yang dimaksud zahir adalah sifat-sifat Allah yang tampak, sedang batin adalah dzat-Nya. Manusia dianggap mempunyai kedua unsur tersebut karena manusia berasal dari pancaran tuhan, sehingga antara manusia dengan Tuhan pada hakikatnya satu wujud, ${ }^{32}$ karena yang mempunyai wujud hanyalah Tuhan.

\footnotetext{
${ }^{29}$ Ahmad Rivauzi, "Pemikiran Abdurrauf...," h. 136.

${ }^{30}$ QS. Luqmān [31]: 20.

${ }^{31}$ QS. al-Hadid [57]: 3.

32Ibn 'Arabi, Fusūs al-Hikām, 2004, h. 185.
} 
Dengan demikian wujud itu hanya satu yakni wujud Allah. Alam ini seperti cermin yang buram dan juga seperti badan yang tidak bernyawa. Dengan kata lain alam ini merupakan penampakan dari $a s m \bar{a}^{\prime}$ dan sifat Allah yang terus menerus. ${ }^{33}$

Abdurrauf menegaskan kewajiban mengesakan Allah dan mengajukan pembuktian keesaan Allah dengan tidak rusaknya alam. Berangkat dari argumentasi ketidakbinasaan alam yang menjadi bukti keesaan Allah, kemudian Abdurrauf menjelaskan hakikat alam sebagai sarana untuk mengetahui atau sebagai bukti dari keberadaan Allah.. ${ }^{34}$ Abdurrauf mengutip karya Ibn 'Arabi35 dalam kitab Fusūs al-Hikām dan Abdurrahman al-Jami' :36

Berkata Syekh Muhyiddin, semoga Allah mensucikan ruhnya, di dalam kitab Fusūs, bunyinya:" Potensi kita pada hakikatnya adalah bayangan Allah, bukan selain Dia". Lebih lanjutnya, Saidina Maulana 'Abdurrahman ibn Ahmad al-Jami' menjelaskan, "Baik potensi tersebut pola dasar luar (a'yān khārijiyyah) atau pola dasar yang tetap (a'yān thabitah)". Karena pola dasar kita yang tetap adalah bayangan dari zat Tuhan yang menyatu dengan keadaan-Nya, sedangkan pola luar kita merupakan bayangan dari pola dasar kita yang tetap itu, dan bayangan dari suatu bayangan adalah bayangan melalui perantara, sekian..$^{37}$

Abdurrauf mendasari pendapatnya di atas, dengan sabda Rasulullah:

$$
\text { كماقال صلى الله عليه وسلم وما خن الا بهوله } 38
$$

${ }^{33}$ Ahmad Rivauzi, “Pemikiran Abdurrauf...," h. 137.

${ }^{34}$ Tanbīh al-Māshi, Ms.B., h. 2-3

${ }^{35}$ Nama lengkapnya adalah Muhammad ibn 'Alī ibn Muhammad ibn 'Arabiyy, Abū Bakar alHātimiyy al-Andalūsiyy (1165-1240), dan digelari dengan Muhyiddin (penghidup agama) dan lebih dikenal dengan sebutan Ibn 'Arabi. Gelar lainnya adalah al-Syaikh al-Akbar (guru yang agung). Ia dilahirkan di Mursia, Spanyol bagian tenggara, kemudian hijrah ke Seville. Ia sering dihubungkan dengan doktrin wahdah al-wujüd, karena dia dianggap sebagai pencetusnya, walaupun dalam karangannya tidak ditemui kalau dia menggunakan istilah itu. Lihat: Oman Fathurrahman, Tarekat Shatāriyyah di Minangkabau, h. 47; Rosihan Anwar. Ilmu Tashawwuf (Bandung: Pustaka Setia. 2000). h. 145 dan Ibn 'Arabi, Fusus al-Hikam, Penj: R.W.J Austin (Yogyakarta: Islamika, 2004).

${ }^{36}$ Nama lengkapnya Nūr ad-Dīn 'Abd ar-Rahmān ibn Ahmad ibn Muhammad al-Jāmi' (14141492. Ia dalah seorang penyair sufi yang berasal dari Persia yang dilahirkan di Kharjad, Khurasan. Di samping seorang sufi, ia juga ahli tafsir dan Hadis. Karya-karyanya tidak kurang dari 90 buah. Lihat: Nasution dkk. Ensiklopedi Islam Indonesia; lihat Oman, Tarekat Shațāriyyah di Minangkabau, h. 47.

${ }^{37}$ Abdurrauf, Tanbīh al-Māshi (Ms.B) h. 3.

${ }^{38}$ Abdurrauf Singkel, Ms.B., h. 5. Penulis belum menemukan matan Hadis ini pada kitab-kitab Hadis yang terkenal seperti al-Bukhari dan lainnya. Namun Hadis ini banyak beredar di kalangan ahli sufi dan kitab-kitabnya. 
"Sebagaimana sabda Rasulullah saw., keberadaan kita semata-mata karena Dia dan milik-Nya."

Di dalam Kitab Bayān Tajalli Abdurrauf menulis:

"Bermula adalah segala sifat yang tujuh pada kita ini bayang-bayang bagi segala sifat Haqq Ta'āla yang telah tersebut itu seperti wujud kita bayangbayang bagi wujud-Nya. Maka bayang-bayang itu tiada ia maujūd melainkan dengan yang empunya bayang-bayang."39

Allah dalam al-Qur'an tidak mengatakan: Qul Allāhu khāliqu 'ainihi (katakan wahai Muhammad! Allah adalah pencipta zat-Nya), akan tetapi Allah mengatakan dalam al-Qur'an: Qul Allāhu khāliqu kullā shai'in (katakan wahai Muhammad! Allah adalah pencipta segala sesuatu). Lanjutnya, di dalam al-Qur'an tidak ditemui, "Segala puji bagi Allah; Tuhan zat-Nya", akan tetapi yang ditemui adalah, "segala puji bagi Allah Tuhan semesta alam". 40

Jika manusia merupakan zat Allah, seharusnya manusia dapat mewujudkan semua yang diinginkannya dengan hanya mengatakan kun, kemudian yang diinginkannya itu akan terjadi dengan sekejap karena di dalam al-Qur'an Allah mengatakan, "Jika Ia menghendaki akan sesuatu, maka Ia akan mengatakan kun, maka terjadilah hal itu dengan sekejap". Namun hal ini tidak berlaku bagi manusia, karena kehendak manusia tidak selalu seiring dengan kehendak Allah. Ini menjadi bukti bahwa alam atau makhluk tidak identik dengan Allah. Untuk menguatkan pendapatnya Abdurrauf mengutip sebuah Hadis Qudsi:

Hai anak Adam, engkau punya keinginan, dan Akupun demikian. Jika engkau pasrah terhadap apa yang Aku inginkan, maka Aku akan memberikan apa yang engkau inginkan. Namun jika engkau menentang apa yang Aku inginkan, Aku akan mempersulit apa yang engkau inginkan sehingga tidak akan terjadi sesuatu kecuali apa yang Aku inginkan. ${ }^{41}$

Abdurrauf tetap memakai istilah waḥdah al-wujūd, namun pengertian dan pemaknaannya berbeda dari konsep waḥdah al-wujūd yang dikemukakan oleh

\footnotetext{
${ }^{39}$ Abdurrauf, Bayān Tajalli, h. 3. Baca juga P. Voorhoeve, Bayān Tajalli; Bahan-bahan untuk Mengadakan Penyelidikan Lebih Mendalam tentang Abdurrauf Singkel, alih bahasa Aboe Bakar, (Banda Aceh: Pusat Dokumentasi dan Informasi Aceh, 1980), h. 26.

${ }^{40}$ Abdurrauf Singkel, Tanbīh al-Māshi, Ms. B.

${ }^{41}$ Abdurrauf Singkel, Tanbīh al-Māsyi, Ms.A., h. 7. Penulis belum menemukan sanad hadis ini. Namun Hadis ini dapat juga ditemukan dalam Ismāî̀ Haqqī bin Mushthafā al-Istanbūlī al-Hanāfì alKhulwat̄̄ al-Maulā Abū al-Fidā' (w. 1127), Rūḥ al-Bayān (Beirut: Dar al-Fikr, t.th.).
} 
Hamzah Fansuri dan as-Sumatrani. Dengan kalimat yang tegas Abdurrauf menulis:

$$
\begin{aligned}
& \text { فنقول هذا مرادهم بوحدة الوجود لأن المراد بها ان العالم ليس موجودا ثانيا مع الحق مستقلا وان الحق } \\
& \text { سبحانه وتعالي هو الواحد الأحد الذي ليس معه كل شئ وهو مع كل شئ أوّالا وأخرا .. }
\end{aligned}
$$

Menurut kami, inilah yang dimaksud dengan waḥdah al-wujūd . Karena yang dimaksud dengan waḥdah al-wujūd adalah bahwa alam bukanlah wujud kedua yang berdiri sendiri bersama al-Haqq, dan bahwa sesungguhnya al-Haqq SWT., Dia Maha Esa yang tidak ada sesuatu pun yang menyamai-Nya, namun Dia selalu menyertai segala sesuatu, baik pada permulaan maupun di akhir... ${ }^{4}$

Menurut Oman,43 reinterpretasi Abdurrauf tentang waḥdah al-wujūd tidak dapat dilepaskan dari konteks controversial di Aceh terutama yang berkaitan dengan doktrin waḥdah al-wujūd. Hamzah Fansuri sebagai pencetus utama dalam hal ini misalnya lebih menekankan imanensi dan transendensi Tuhan dengan alam secara mutlak. Hamzah Fansuri menganalogikan hubungan antara Tuhan dengan alam tersebut seperti laksana biji dengan pohonnya. Meskipun ada dua benda, namun pada hakikatnya satu jua. Dalam karyanya al-Muntahī, Hamzah menulis:

"Seperti sebiji dan pohon; pohonnya adalah yang sebiji itu, sesungguhnya tiada kelihatan, tetapi hukumnya ada dalam biji itu."

Hamzah Fansuri juga mengumpamakan hubungan Tuhan dengan alam ini dengan laut dan ombak.

Laut itu qadim; apabila berpalu, baharu ombak namanya dikata, tetapi pada haqīqatnya laut jua, karena laut dan ombak esa tiada dua. ${ }^{44}$

Hamzah Fansuri menganalogikan hubungan antara Tuhan dan alam itu dengan matahari, cahaya dan panasnya. Menurutnya, meskipun kelihatannya tiga, pada hakikatnya satu juga: "Seperti matahari dengan cahayanya dengan panasnya; namanya tiga haqīqatnya satu jua". 45

${ }^{42}$ Tanbīh al-Māsyi, Ms.A., h. 8.

${ }^{43}$ Oman, Tanbīh al-Māsyi Menyoal, h 53. Lihat juga: Muhammad Naquib Al-Attas, The Mysticism of Hamzah Fansuri (Kuala Lumpur: University of Malaya Press. 1970), h. 330.

${ }^{44}$ Oman, Tanbīh al-Māshi: Menyoal...,h. 53.

${ }^{45}$ Ibid. 
Walaupun menggunakan analogi yang sama "alam adalah bayangan dari Allah", namun Hamzah Fansuri lebih menekankan akan persamaan yang mutlak antara Tuhan dengan alam yang merupakan bayangannya. Hal ini yang membedakannya dengan Abdurrauf yang membantahnya dengan mengatakan bahwa walaupun alam itu bayangan Tuhan tetapi tetap berbeda secara eksistensialnya. Allah tetap Tuhan dan alam tetap alam adanya.

Dalam al-Muntahī, Hamzah menulis:

Adapun dirinya itu, sungguh (pun) beroleh nama dan rupa itu, haqiqat-nya rupanya dan namanya tiada. Seperti bayang-bayang dalam cermin; rupanya dan namanya ada, (haqiqat-nya tiada)... maka hamba-Nya yang khäsh pun namanya mukmin. Jika demikian, sama-sama dengan Tuhannya, karena hamba tiada bercerai dengan Tuhannya, dan Tuhan pun tiada bercerai dengan hamba-Nya. ${ }^{46}$

Konsep dan interpretasi Abdurrauf Singkel tentang Waḥdāt al-wujud ini merupakan landasan pemikiran tasawuf Abdurrauf Singkel dalam menjelaskan hubungan ontologis antara Allah, manusia dan alam semesta serta proses penciptaan manusia dan alam semesta.

\section{Al-Fa'id (Emanasi)}

Menurut Abdurrauf, alam tercipta melalui proses pemancaran (al-fa'id atau emanasi) dari zat Allah. Wujud alam itu tidak benar-benar berdiri sendiri, melainkan terjadi melalui pancaran, bagaikan memancarnya pengetahuan dari Allah. Seperti halnya alam ini bukan benar-benar zat Allah (al-Haqq), karena ia merupakan wujud yang baru. Alam juga tidak benar-benar lain dari-Nya secara mutlak, karena hal itu tentu akan ada wujud kedua yang berdiri di samping zat Allah. Sebab sebagaimana pada zaman azali, tidak ada yang menyertai Allah, karena Dia adalah yang pertama ada sebelum segala sesuatu tercipta, demikian halnya hingga sekarang. Alam itu baru, karena ia tercipta dari pancaran wujudNya, ia bukan wujud yang menyertai-Nya, tetapi wujud yang diciptakan-Nya. Jadi alam itu tidak memiliki derjat yang sejajar dengan Allah, melainkan berada di tingkat di bawah-Nya. ${ }^{47}$

${ }^{46}$ Ibid.

${ }^{47}$ Lihat: Ms.A., h. 7.

JURNAL THEOLOGIA — Volume 28, Nomor 2, Desember 2017 
Abdurrauf berusaha mempertahankan pandangan transendensi Tuhan atas ciptaan-Nya (tanzīh).48 Untuk menguatkan pandangannya tentang transendensi Tuhan dari ciptaan-Nya ini, dia mengutip Hadis Nabi:

$$
\text { كان اللهولاشئ معه ... }
$$

"Allah tetap seperti ada-Nya, tidak ada suatupun yang menyertai-Nya". 49

Abdurrauf juga mengutip pendapat dan keterangan para ulama yang mengatakan:

$$
\text { وهو الأن على ما عليه كان ... }
$$

"Keadaan Allah sekarang sama dengan keadaan-Nya dahulu".

Untuk menguatkan argumentasi emanensi Tuhan atas ciptaan-Nya, Abdurrauf mengutip firman Allah: وهو مeكم أينما كتتم (dan Dia bersama kamu di mana saja kamu berada). ${ }^{50}$

Segala sesuatu tidak diciptakan dari sesuatu yang tiada, melainkan dengan rahmat-Nya dan yang pertama diciptakan adalah cahaya Muhammad:

Maka, dengan rahmat-Nya itu, Allah mewujudkan dan menciptakan segala sesuatu itu sesuai dengan pengetahuan-Nya pada zaman azali secara tertib. Adapun makhluk yang pertama kali diciptakan oleh Allah Ta'äla adalah ruh Nabi sebagaimana sabda Nabi ketika ditanya oleh Jabir tentang makhluk yang pertama kali diciptakan oleh Allah. Sa'at itu Nabi menjawab, "Wahai Jabir! Sesungguhnya sebelum menciptakan segala sesuatu, Allah menciptakan cahaya Nabimu dari cahaya-Nya. Lalu Dia menjadikan cahaya itu berputar-putar dengan kehendak kekuasaan-Nya, dan pada waktu itu belum ada lauh, pena, sorga, neraka, malaikat, langit, bumi, matahari, bulan, jin ataupun manusia. Maka tatkala Allah mau menciptakan makhluk yang lain , Dia membagi cahaya itu menjadi empat bagian, dari bagian pertama Dia menciptakan pena, bagian kedua lawh, dari bagian ketiga 'arash. Kemudian

${ }^{48}$ Lihat Oman, Tanbīh al-Māshi: Menyoal ., 1999, h. 50-51.

${ }^{49}$ Menurut al-'Ajilūni (1087-1162 H/1676-1749), Hadis ini diriwayatkan oleh Ibn Hibban, Hakim, dan Ibn Abi Syaibah dari Baridah. Namun dalam riwayat lain sebagaimana juga diterangkan oleh Abdurrauf, adanya ungkapan tambahan "و هو الآن على ما عليه كان "merupakan ungkapan dari orang-orang sufi. Lihat, Ismāill bin Muhammad bin 'Abdu al-Hādi al-Jarāhī al-'Ajilūnī al-Damshiqī, Kashfal-Khafa'( Kairo, Maktabah al-Qudsi, 1351).

${ }^{50} \mathrm{QS}$. al-Hadid [57]: 4. 
bagian yang keempat Dia bagi bagi menjadi empat bagian. Dari bagian pertama Dia ciptakan hamalah 'arash, dari bagian kedua kursi, dan dari bagian ketiga malaikat. Kemudian bagian keempatnya dibagi lagi menjadi empat bagian. Dari bagian pertama Dia ciptakan langit, dari bagian kedua bumi, dari bagian ketiga sorga dan neraka. Kemudian bagain keempatnya dibagi lagi menjadi empat bagian. Dari bagian pertama Dia menciptakan cahaya orang mukmin, bagian kedua cahaya hati mereka yaitu ma'rifat kepada Allah, dan dari bagian ketika cahaya kemanusiaan yaitu cahaya lā ilāha illā Allāh Muhammad Rasūlullāh. ${ }^{51}$

Proses penciptaan alam (al-fãid), dijelaskan Abdurrauf melalui konsep martabat tujuh:

Dan seyogianya kita ketahui dan kita i'tikadkan bagi Haqq Ta'āla itu tujuh martabat, yakni mempunyai ia akan tujuh martabat dengan ijmāl, pertama martabat ahādiyat namanya, kedua martabat wahdat namanya, ketiga martabat wāhidiyat namanya, keempat martabat 'àlam arwah namanya, kelima martabat 'alam mithāl namanya, keenam martabat 'ālam ajsām namanya, ketujuh martabat 'âlam insān namanya. Maka tiga yang pertama itu martabat ketuhanan dan empat yang kemudian itu martabat kehambaan lagi mazar bagi Haqq Ta'âla ${ }^{52}$

Dalam Bayān Tajalli, Abdurrauf tidak memberikan penjelasan rinci tentang martabat tujuh tersebut, namun pada bagian lain naskah ditemukan teks martabat tujuh yang menjelaskan tentang martabat tujuh:

Ahādiyah adalah martabat zat Allah, wahdah adalah martabat sifat Allah sedangkan wāhidiyyah adalah martabat asmā' Allah. Sedangkan 'alām ar$w \bar{a} h$ adalah alam segala ruh (nyawa), 'ālam mithāl adalah alam segala rupa,

${ }^{51}$ Tanbih al-Māshi, Ms.B.., h. 16. Penulis menjumpai hadis ini dalam kitab-kitab ahli shufi. AlZurqānī dalam Syarah al-Mawāhib menjelaskan bahwa hadis ini mengandung makna bahwa ungkapan "min nūrihi" pada hadis ini menunjukkan kemulyaan dan menjelaskan bahwa nur itu adalah sesuatu yang misteri. Hadis ini juga menjelaskan bahwa nur dan penciptaan nur tersebut dihubungkan dengan kehendak Allah yang tidak memeliki perantara sesuatu dalam mengadakannya. Lihat, Muhammad 'Abd al-Hayyi bin Muhammad 'Abd al-Halīm al-Anshāri al-Laknawi al-Hindi (w. 1304 H), al-Athār al-Marfü'ah fi al-Akhbāri al-Mawḍ̄'ah, Muhaqqiq: Muhammad al-Sa'id Basiyūnī Zaghluli (Baghdad: Maktabah al-Syarq al-Jadīd, t.th).

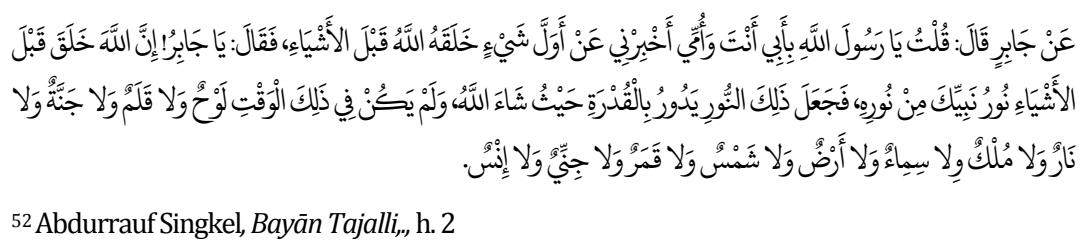

JURNAL THEOLOGIA — Volume 28, Nomor 2, Desember 2017 
'ālam ajsām adalah alam segala tubuh, sedangkan 'alām insān adalah alam segala manusia. ${ }^{53}$

Selanjutnya berdasarkan keterangan yang diperoleh dalam kitab teks martabat tujuh tersebut, penjelasannya sebagai berikut:

Pertama aḥādiyah artinya esa. Ahādiyah adalah nama wujūd muțlāq atau martabat hakikat zat Allah. Martabat zat ini disebut juga, wujūd muḥadh, ghāib al-ghuyūb, ta'yun nafsah, lā ta'yin, belum nyata sesuatu dalam ilmu-Nya. Martabat ini dapat diumpamakan seorang tukang yang belum memikirkan apa yang mau diperbuatnya. Qadìm. Nama zat pada martabat ini Hua.

Kedua, wahdah berarti yang punya esa. Disebut juga dengan wujud dan sifat. Pada martabat ini zat sudah bercampur dengan sifat ilmu yang ijmali atau global. Wahdah disebut juga dengan martabat sifat (shu'un dzat) bersifat qadìm, baqa, atau sering juga disebut dengan haqìqat muhammad ('ālam mujmal), nur Allah, insān kāmil. Pada martabat ini nama zat adalah "Allah". Martabat ini merupakan ta'yin awal, nyata sesuatu dalam ilmu-Nya. Hakikat Muhammad yaitu rupa dan tempat nyata bagi wujud Allah atau bayang-bayang ahadiyah.

Ketiga wāhidiyyah adalah yang esa. Wāhidiyyah (Yang Esa). Disebut juga dengan martabat asmā', nūr muhammad, hakikat adam, (fa'id al-quds), hakikat insan, tubuh kita yang halus (a'yān thabitah ) yang tiada mati, hakikat adam atau nūr muḥammad ('ālam mufașșal). Martabat ini merupakan tajalli sifat atau wujud 'am yang tujuh: 'ilmu, kalam, qudrat, iradah, sama', bașar, hayat.' A'yān thābitah punya dua wajah yaitu, wajah berhadap kepada wujud, dan wajah berhadap kepada a'yān khārijiyyah. Martabat ini merupakan ta'yin tsāni (semakin nyata sesuatu dalam ilmu-Nya). A'yān thābitah merupakan tempat nyatanya wujud rahman yang merupakan bayang-bayang wahdah yaitu wujud, sifat, dan asma' yang ma'lūm secara mufașsal (rinci).

Keempat, 'ālam arwāh (ruh), żāhir asmā' dan afōàl. Martabat ini disebut juga dengan martabat ruh yang muhaddits lagi fāna, atau disebut juga fā'id almuqaddas, muhammad, Nurani, nur alam, ta'yīn thālis (tiga). Ruh adalah segala nyawa tempat nyatanya nur bayang-bayang wāhidiyah.

${ }^{53}$ Kitab Martabat Tujuh ini tidak disebutkan siapa penulisnya. Namun pada naskan tersebut terdapat beberapa teks karya Abdurrauf, di antaranya Bayān Talalli, Daqāiq al-Hurūf, Tanbih alMāshi. dan beberapa karya lainnya yang tidak disebutkan penulisnya bahkan judul teksnya. Karena teks tersebut memuat pembahasan tentang martabat tujuh, maka penulis menamainya Teks Martabat Tujuh. 
Kelima, 'ālam mithāl ('alam segala rupa). Pada martabat ini z̦āhir afōl pada rupa yang bersifat muhaddith lagi fäna. Martabat ini adalah martabat rupa sekaliam manusia yang nurani, lațif, terperinci atau disebut juga rupa Muhammad. Nama zat pada martabat ini adalah mușawwir. Martabat ini merupakan ta'yin keempat (rābi') , tempat nyatanya wujud musawwir dan merupakan bayang-bayang alam arwah.

Keenam, 'àlam ajsäm (tubuh). Ini merupakan martabat tubuh, muhaddits lagi fāna dan masih terkategori alam malakut. Martabat ini disebut juga dengan tubuh yang kasar, yang terdiri dari empat anashir, air, api, angin, tanah, dapat dilihat dengan mata kepala. Martabat ini merupakan ta'yin kelima (khāmis), tempat nyata wujud atau zāhir dan bayang-bayang alam arwah.

Ketujuh, 'ālam insān (manusia). Ini merupakan martabat manusia, muhaddits lagi fāna. Disebut juga dengan 'ālam nasut. Pada martabat ini żāhir ke-Tuhanan dan kehambaan lagi jāmi' (terhimpun). Ini merupakan ta'yin keenam, tempat nyata zāhir wujūd jāmi' (berhimpun semua martabat). ${ }^{54}$

Tajalli Allah melalui ciptaan-Nya bahkan dapat terlihat pada rangka bangun tubuh manusia itu sendiri. Nama Allah tergambar dalam wujud lima jari manusia. Nama Allah terdiri dari empat huruf. Pertama alif dan kedua lam, dan ketiga lam akhir dan keempat $h a$. Jari kelingking merupakan gambaran dari huruf alif, dan jari manis, lam awal, dan jari tengah huruf lam thani dan jari tunjuk. Sedangkan ibu jari gambaran huruf $h a$. Wujud insan itu kalimah nama Allah dan nama Rasulullah yaitu Muhammad. ${ }^{55}$ Firman Allah pada Hadis Qudsi menjelaskan:

... tubuh manusia, dan nafsunya (diri atau jiwanya) dan hatinya, dan arwahnya, dan telinganya, dan matanya, dan lidahnya, dan tangannya, dan kakinya, dan sekalian itu akan kenyataan bagi-Nya, dengan dalil, "bagi dirimu, tiada insan itu lain dari pada Aku, Aku pun tiada lain dari padanya". seperti firman-Nya: "insan rahasia Aku, dan Aku pun rahasinya, sifat Aku, tiada selain Aku. ${ }^{56}$

Manusia dimuliakan karena ditupkannya oleh Allah ruh-Nya yang suci padanya. Sebagaimana dijelaskan Allah dalam firman Allah, "Aku tiupkan kepadanya ruh-Ku. Adapun tubuh adam, hakikatnya tubuh muhammad, tubuh

${ }^{54}$ Teks Martabat Tujuh, t.th.

${ }^{55}$ Abdurrauf Singkel, Daqā'iq al-Hurüf, h. 1.

${ }^{56}$ Ibid.

JURNAL THEOLOGIA — Volume 28, Nomor 2, Desember 2017 
muhammad hakikatnya tajalli af al Allah. Adapun hati Adam hakikatnya hati muhammad, hati muhammad hakikatnya tajalli $a s m \bar{a}^{\prime}$ Allah. Adapun nyawa adam hakikatnya nyawa muhammad, nyawa muhammad hakikatnya tajalli sifat Allah. Adapun rahasia adam hakikatnya rahasia Muhammad. Rahasia Muhammad hakikatnya tajalli zat Allah ${ }^{57}$

Pada teks kitab Daqā'iq al-Ḥurūf, juga ditemukan penjelasan tentang "insan kamil". Insan kamil yang dimaksudkan Abdurrauf adalah seseorang yang mukmin, yang mendapat pencerahan batin dari Allah sehingga dia memperoleh pandangan rahmat dari Allah Swt, yang diberikan rupa oleh Allah dengan rupa "muhammad" (rupa yang dipuji), dan inilah yang dmaksudkan dengan "khaliffah fi 'l-ard". Berbeda halnya dengan orang kufur, maka rupanya dirupakan dengan rupa yang jelek. Rupa yang jelek dan bagus dalam pengertian di sini bermakna maknawi, bukan zāhiriyyah. ${ }^{58}$

Terdapat dua nama yang menurut Abdurrauf tidak boleh digunakan untuk manusia, yaitu wājib al-wujūd dan ghinā al-muțlāq. Wājib al-wujūd adalah nama Allah semata, karena Dia yang wujudnya tiada permulaan dan tiada akhir. Sementara ghinā a al-muțlā q berarti hannya Allah yang kaya sesungguhnya, Dia menciptakan, dan mewujudkan segala sesuatu dengan mudah atau hannnya dengan kata "kun" maka jadilah. ${ }^{59}$

\section{Pendekatan dan Cara Mengenal Allah sebagai Hakikat Wujud}

Akal tidak mampu mendapatkan atau mencapai hakikat wujud Allah karena akal itu adalah sesuatu yang diciptakan. Hanya berkat karunia Allah dalam bentuk dibukakan-Nya hati hamba-Nya dengan cahaya iman dan taufiq, manusia dapat mengetahui hakikat. Maka Allah mencelup hati seorang hamba dengan cahaya zat Allah sehingga menjadi nyata sifat Allah pada hati yang batin yang kemudian berbekas pada hati yang zahir dan tubuh lahiriyyah. Ketika zahir dan nyata cahaya iman itu pada tubuh hamba, maka tubuh itu akan menjadi laksana cermin. ${ }^{60}$

\footnotetext{
${ }^{57}$ Ibid., h. 2

${ }^{58}$ Ibid., h. 2-3.

${ }^{59}$ Ibid., h. 3.

${ }^{60} \mathrm{Ibid}$. , h. 4-5.
} 
Ketika seorang hamba melihat tubuhnya, maka tubuh itu merupakan cerminan ruh (nyawa). Abdurrauf mengatakan bahwa rupa ruh seorang hamba sama dengan rupa tubuhnya cuma perbedaannya, yang satu halus lagi batin, dan yang satu lagi kasar. Ruh (nyawa) adalah tempat nyata atau tajalli sifat Allah yang tujuh, dan sifat itu tempat nyata zat Allah yang tiada serupa dengan makhluk-Nya melainkan sebagai bayangan dari wujud Allah. Zat Allah berbayang dengan sifat, sifat Allah berbayang pada ruh (nyawa) dan nyawa berbayang pada tubuh. ${ }^{61}$

Selanjutnya, pada bagian akhir teks ini Abdurrauf juga mengajarkan cara menyatukan diri dengan Allah:

Maka di-taraqa-kanlah pandang itu oleh 'ārif artinya dinaikkannya pandangannya oleh 'ârif. Pertama-tama pandangannya difānakannya sekalian tubuhnya di dalam nyawanya dan diisbatkannya nyawanya. Kemudian difānakannya nyawanya di dalam sifat Allah, diitsbatkannya Allah Ta’āla semata-mata pada batinnya, maka dikatanya lā ilāha illā Allāh artinya tiada nyawaku dan badanku hannyalah yang ada itu Allah wajib ada-Nya, maka senantiasa kita pandang demikian berjalan, atau diam, dan duduk atau berdiri dalam sehat atau sakit kita, wallāhu a'lamu bi ' l-șawābi.62

Kutipan di atas, agaknya merupakan kunci dari tata cara merasakan dan menemukan pemahaman yang sejati sebagai bayangan dari wujud Allah atau memahami konsep waḥdāt al-wujūd .

Tidak mungkin bagi manusia untuk mengetahui hakikatnya sendiri yang paling dalam, yakni ruh. Jika untuk mengenali hakikat dirinya saja tidak akan mampu, maka akan lebih tidak mampu lagi mengenali hakikat Allah; yang tiada sekutu bagi-Nya, dan zat yang Maha Sempurna. Maka hal yang bisa dilakukan oleh manusia adalah mengenali kehambaannya di hadapan Allah, sebagaimana terlukiskan dalam tulisannya dalam bentuk bantahan terhadap penafsiran terhadap Hadis "man 'arafa nafsahu, fa qad 'arafa rabbahu" yang sering diartikan secara keliru. Abdurrauf mengatakan:

Katakan dan yakinkan bahwa hamba tetap hamba meskipun ia naik pada tingkat yang tinggi (tarāqi), dan Allah tetap Allah meskipun Ia turun (tanāzul). Dan hakikat itu tidak akan berubah, artinya hakikat hamba tidak

${ }^{61}$ Ibid.

${ }^{62}$ Ibid., h. 5-6. 
akan berubah menjadi hakikat Allah, demikian pula sebaliknya, walau pada zaman azali sekalipun. Dan janganlah engkau terperdaya oleh orang yang berdalih atas penyatuan wujud hamba secara total dengan dasar Hadis: "Barang siapa mengenal dirinya, niscaya mengenal akan Tuhannya",63 lalu, dalam ketidak tahuanya kepada Allah ia menafsirkan Hadis itu dengan mengatakan, bahwa diri manusia itu adalah benar-benar zat Tuhannya, tidak lain dari itu. Kami berlindung kepada Allah dari keyakinan demikian. Adapun arti Hadis itu sebenarnya adalah, sebagaimana dikatakan oleh Abu Hasan Syazili "Barang siapa mengenal dirinya fakir, niscaya dia mengenal Tuhannya Maha Kaya, barang siapa mengenal dirinya lemah, niscaya dia akan mengenal Tuhannya Maha Kuat, barang siapa mengenal dirinya tak kuasa, niscaya dia akan mengenal Tuhannya Maha Kuasa, dan barang siapa mengenal dirinya hina, niscaya dia akan mengenal Tuhannya Maha Mulia", sekian. ${ }^{64}$

Dari kutipan di atas tergambar bahwa epistemology yang dipakai Abdurrauf adalah dalil-dalil naql, dan dengan menanamkan kesadaran kehambaan (dzauq) yang menyadari keterbatasan-keterbatasan kehambaan. 65

Abdurrauf juga mengutip firman Allah " Katakan wahai Muhammad, bahwa ruh itu adalah urusan Tuhanku” (QS. Al-Isra'[17]: 85, dan sebuah sya'ir:

Engkau tidak mengenal dirimu dan tidak tahu siapa dirimu, tidak bagaimana proses kehadiranmu dan sifat-sifat yang ada padamu, sebab akal tidak akan mampu menjangkaunya. ${ }^{66}$

Selanjutnya Abdurrauf menyimpulkan:

Atas dasar ini, tidak ada jalan lain untuk mengenal al-Haqq kecuali dengan pengakuan diri lemah dan bingung. Karena, seperti nanti akan dijelaskan, dua hal ini merupakan puncak ma'rifat. Pahamilah, dan hannya kepada Allah kita mohon petunjuk. ${ }^{67}$

\footnotetext{
${ }^{63}$ Menurut al-Sam'ani, ungkapan ini bukan Hadis Nabi, melainkan kata-kata hikmah dari Yahya al-Razi. Sedangkan ulama lain, seperti Ibnu Taimiyah dan al-Sagani, menganggapnya sebagai Hadis palsu. Mempertimbangkan kemasyhurannya sebagai Hadis di kalangan sufi, tampaknya ia dianggap sebagai 'Hadis' sahih dan benar berdasarkan mukasyafah atau penyingkapan [yakni, visi mistis], tapi dipandang tidak sahih berdasarkan jalur riwayatnya. (lihat Azhari, 1985: 111) dan Oman Fathurahman, 2008, 142.

${ }^{64}$ Tanbīh al-Māshi, Ms.B., Ibid., h. 9, dan Ms.A., h. 10-12.

${ }^{65}$ Ahmad Rivauzi, “Pemikiran Abdurrauf Singkel...”, h. 153.

${ }^{66}$ Abdurrauf Singkel,Tanbih al-Masi, Ms.B. h. 11, Ms.A. h 12.

${ }^{67}$ Ibid.
} 
Proses dalam mengenali Allah adalah melalui proses tarāqi dalam upaya mengembalikan a'yan khārijiyyah kepada kesadaran a'yān thābitah sebagai bentuk upaya spiritual seseorang untuk mencapai posisi puncak spiritual. Upaya ini diawali dengan menghadirkan kesadaran kehambaan di hadapan Allah dengan mengharapkan rahmat-Nya, sehingga kemudian Allah membukakan rahmat-Nya kepada hati hamba, sehingga tajalli lah sifat-sifat ke-Tuhanan pada diri hamba itu. Diawali dengan menyadari keberadaan nyawa yang bentuk rupanya sama dengan rupa tubuh. Tubuh merupakan rupa zahir, dan nyawa adalah rupa yang halus dan batin. Nyawa adalah tempat nyatanya semua sifat Allah yang tujuh. Sifat Allah adalah tempat nyatanya Zat Allah, sedangkan Zat Allah tidak ada yang menyerupainya sesuatupun baik pada alam zahir maupun alam batin. Zat bayangannya adalah sifat, sifat itu bayangannya adalah nyawa, dan nyawa itu bayangannya adalah tubuh. Maka dilakukan proses taraqi (dinaikkan) pandang dengan cara difānakannya sekalian tubuhnya di dalam nyawanya dan diitsbatkannya nyawanya. Kemudian difânakannya nyawa di dalam sifat Allah, diitsbatkannya Allah taala semata-mata pada batinnya. Maka diucapkan لע اله الا اله dengan pengertian, tiada nyawaku dan badanku, yang wajib ada hannya Allah. 68

\section{Memahami Hakikat Kematian}

Abdurrauf menjelaskan dua bentuk mati. Pertama, mati ikhtiyari yaitu ketika manusia dalam keadaan karam (tenggelam dalam kemuliaan) dalam zikrullah. Kedua, mati idhtirari yang bukan atas dasar pilihan atau ikhtiyar kita. Mati ini disebut juga dengan berpisahnya roh dengan jasad. Pembahasan Abdurrauf tentang hal mati ini dapat dijumpai dalam beberapa karyanya seperti Tanbih al-Māshi, Bayān Tajalli, dan pada kitab Lubb al-Kasyf wa al-Bayān limā yarāhu al-Muhtadhar bi al-i'yan. Dalam penjelasannya, Abdurrauf mengutip sebuah Hadis dari Rasulullah: موتوا قبل ان تموت (matilah kamu sebelum kamu dimatikan). ${ }^{69}$

${ }^{68}$ Abdurrauf, Daqāizq al-Huruf, h. 4-6.

${ }^{69}$ Menurut Ibn Hajar, Hadis ini tidak memiliki sanad yang jelas. Al-Qārī berpendapat bahwa ungkapan ini merupakan perkataan para ahli shufi, yang memiliki makna "mati ikhtiyari dengan meninggalkan syahwat sebelum mati yang sebenarnya". Terdapat juga kemungkinan Hadis ini memang berasal dari Rasul dengan sanad yang berasal dari kalangan ahli sufi. Baca, Al-'Ajilūni, Kasyf al-Khafa' (Juz 2 h. 384). 
Abdurrauf dalam Bayān Tajalli menulis:

Maka dengan kata ini, adalah mati itu dua bagi. Suatu mati idhtirari namanya. Maka itu zuăhir tiada masuk dalamnya ikhtiyari. Kedua, mati ikhtiyari namanya, itu masuk dalamnya ikhtiyari, dengan memfänakan diri dan mengembalikan dia kepada hal 'adam-nya (pen: ketiadaan) yang telah tersebut itu. Bermula sebesar-besar jalan dan sehampir-hampir jalan لاله الا اله zepada ikhtiyari itu yaitu karam (pen:tenggelam) dengan zikir karena hasil makna لااله الا اله itu pada orang yang muntahi tiada maujud hannya Allah, karena segala yang maujud yang lain dari pada Allah itu bayang-bayang jua bagi Haqqq Ta'āla, tiada ia maujud sendirinya hanya dengan Dia jua berdiri wujud itu dan milik bagi-Nya. Maka tiadalah maujud hakiki hannya Allah jua. ${ }^{70}$

Dengan demikian, seseorang akan disebut mengalami mati ikhtiyari ketika yang bersangkutan sampai kepada kondisi mental yang telah mampu memandang tiada yang hidup, tiada yang tahu, tiada yang kuasa, tiada yang berkehendak, tiada yang mendengar, tiada yang melihat, dan tiada yang berkatakata pada hakikatnya selain dari pada Allah. Pada kondisi ini maka seseorang akan sampai kepada kesadaran 'adam-nya (pen; ketiadaannya) ${ }^{71}$

Abdurrauf mengutip pembahasan tentang kematian ini di antaranya merujuk kepada kitab Tadhkirah karangan Syaikh Djamaluddin r.a bin Muhammad bin Ahmad al-Qurtubi. Menurut Djamaluddin, setengah ulama menceritakan bahwa seorang hamba Allah apabila ia dalam keadaan sekarat maut maka datang dua orang setan yang duduk di kanan dan kirinya. Setan yang sebelah kanan akan merupakan dirinya seperti rupa bapaknya dan ia berkata: “ hai anakku, aku menyayangi dan mengasihi engkau, maka matilah engkau dengan agama Nasrani, dan ialah sebaik-baik agama. Sedangkan setan yang sebelah kiri akan merupakan dirinya dengan rupa ibunya dan berkata: " hai anakku, bahwasannya perutku adalah bejanamu, air susuku minumanmu, dan pahaku kedudukanmu, matilah kamu atas agama yahudi, dan ialah sebaik-baik agama. $^{72}$

Di samping itu, setan juga akan menyuruh tentaranya memperdaya orang yang sakarat maut dengan menyerupai sahabat, dan orang-orang disayangi si

\footnotetext{
${ }^{70}$ Abdurrauf Singkel, Bayān Tajalli, t.th., h. 4-5.

${ }^{71}$ Ahmad Rivauzi, “Pemikiran Abdurrauf Singkel ...”, h. 157.

72P. Voorhoeve, Bayān Tajalli; h. 8-9.
} 
sakarat maut dan membujuknya untuk mati dalam agama nasrani dan yahudi. Maka bagi orang yang dikehendaki-Nya sesat akan cendrung hatinya kepada ajakan itu. Sedangkan orang yang dikehendaki Allah mati dalam keadaan bertauhid, maka Allah akan menyuruh Jibril (malaikat rahmat) datang kepadanya, mengusir segala setan dan menyapu muka si sakarat maut sehingga tersenyumlah si sakarat maut. Malaikat rahmat akan berkata kepadanya: "hai fulan, tiadalah kau mengenalku. Aku ini adalah Jibril, matilah engkau atas agama yang suci dan syari'at yang benar". Kemudian malaikat maut akan mengambil nyawanya dengan membaca salam dan berkata: " hai wali Allah, sesungguhnya Allah mengirimkan salam kepada engkau, QS. al-Nahl [16]: 32"73

Abu al-Hasan Tāsi dalam kitab Tadzkirah menjelaskan bahwa setiap ruh yang keluar dari tubuh akan diterbangkan malaikat ke atas tujuh petala langit hingga sampai ke 'Arasy Allah, lalu didirikan di hadapan Allah. Allah akan menanyainya, jika ruh itu adalah orang yang mukmin, maka Allah akan berfirman kepada semua malaikat: "Hai malaikat-Ku, bawalah orang ini dan perlihatkanlah kepadanya surga tempat tinggalnya!". Malaikat lalu membawanya berjalan-jalan ke surga sekira-kira masa mayat orang itu dimandikan. Maka apabila telah selesai mayat itu dimandikan dan dikafani, maka dikembalikanlah ruh itu ke sisi tubuh dan kafan mayat. Sehingga ketika mayat dibawa ke kubur, ruh akan mendengar setiap orang yang mengatakan kebaikan si mayat dan kejahatannya. Ketika mayat telah dimasukkan ke dalam kubur, maka ruh itu akan dikembalikan ke tubuhnya, kemudian dia akan didudukkan dan ditanyai oleh dua orang malaikat Allah. ${ }^{74}$

Abdurrauf menjelaskan tanda-tanda ajal mati yang dikutipnya dari kitab Tibb al-Mar'i min Nafsihi. Ada tiga tanda yang dapat dipedomani seseorang sebagai tanda-tanda ajal mati akan datang. ${ }^{75}$

Pertama, pada waktu terbit matahari dan telah terang cahayanya, maka hendaklah seseorang itu berdiri pada tanah yang datar dengan posisi matahari tepat di belakangnya. Dia harus berdiri lurus tanpa bergerak, lalu melihat bayang-bayangnya dengan sekali lihat dengan tidak boleh melihat kebelakang

${ }^{73}$ Abdurrauf Singkel, Bayān Tajalli, h. 4.

${ }^{74}$ Ibid. h.9-14.

${ }^{75}$ Ibid

JURNAL THEOLOGIA — Volume 28, Nomor 2, Desember 2017 
dan tidak boleh berpaling. Maka seseorang itu akan melihat satu sosok warna putih yang merupakan bayangan dirinya. Jika dia melihat bayangan itu tanpa kepala, maka itu adalah isyarat umurnya hannya tinggal kurang dari tiga hari, jika didapatnya bayangan tanpa kedua teliga, niscaya adalah sisa umurnya lima belas hari, jika didapatnya bayangan tanpa satu telinga, itu artinya umurnya tinggal satu bulan. Jika didapatnya bayangan tanpa batang leher, itu artinya umurnya kurang dari tujuh hari lagi. Jika didapatnya bayangan tanpa dua tangan, maka sisa umurnya kurang dari enam bulan. Jika didapatnya bayangan tanpa satu tangan, maka umurnya tinggal satu tahun. Jika didapatnya bayangan tanpa dua kaki, maka umurnya tinggal dua tahun, begitu seterusnya tanpa kaki sebelah dan seterusnya.

Kedua, tanda ajal itu dapat juga diketahui dengan mempedomani bayangan dalam cermin. Jika tidak didapati suatu bayanganpun dalam cermin, maka hampirlah ajalnya pada hari itu. Jika tidak terlihat bayang-bayang hidungnya, maka umurnya kurang tiga hari lagi. Jika didapati bayangan tanpa kedua mata, maka umurnya kurang enam hari lagi. Jika tidap didapati bayangan dua belah matanya maka umurnya tinggal enam bulan. Jika tidak didapati bayangan dua belah keningnya, maka umurnya tinggal dua tahun. Jika tidak dapat terlihat bayangan dahinya, maka umrnya sudah hampir pada hari itu. Demikian selanjutnya dengan bayangan semua anggota badannya yang lain seperti anak jari dan lainnya. Hal ini berlaku bagi orang yang sakit dan tidak sakit.

Tanda ketiga, apabila keluar dari qubul dan dubur-nya buang air besar dan kecil bercampur pada satu tempat keluar maka ini juga menunjukkan ajlanya sudah hampir datang.

Namun demikian, menurut Abdurrauf, bahwa tanda-tanda di atas merupakan tanda-tanda yang berlaku menurut kebiasaan (ghalib) dan tidak berlaku tetap pada setiap manusia, karena terkadang bisa jadi juga kematian manusia tanpa didahului oleh munculnya tanda-tanda tersebut, dan terkadang sering juga semua tanda-tanda itu sudah terdapat pada seseorang, namun dia tidak mati juga. Prinsip utamanya adalah bahwa Allah berbuat sekehendaknya, oleh karena itu, tidak boleh berpatokan terhadap ada atau tidaknya tanda-tanda tersebut untuk kematian seseorang karena tidak ada seorang manusiapun yang dapat mengetahui kapan dia akan mati kecuali Allah yang memberitahunya. Kematian itu merupakan sesuatu yang gaib dan tidak ada yang mengetahuinya selain Allah "... Dan tiada seorang pun yang dapat mengetahui (dengan pasti) apa 
yang akan diusahakannya besok. Dan tiada seorangpun yang dapat mengetahui di bumi mana dia akan mati. ... (QS. Luqman [31]: 34)”76

Selanjutnya dalam teks Lubb al-Kashf wa al-Bayān limā Yarāhu alMuhtadhar bi 'l-I'yan, juga dijelaskan tentang dzikir yang terafdhal di saat sakarat maut yang juga termasuk persoalan yang ditanyakan kepadanya. Dzikir terafdhal ketika sakarat al-maut adalah dzikir lā ilāha illallāh. ${ }^{77}$

\section{Tujuan Penciptaan}

Dalam hal tujuan penciptaan, Abdurrauf merujuk kepada al-Qur'ān yang mengajarkan bahwa tujuan penciptaan manusia adalah menjadi hamba Allah dan menyesuaikan semua prilaku dengan kehendak Allah dan hal-hal yang termaktub di dalam kitab suci al-Qur'an "Hai manusia, sembahlah Tuhanmu Yang telah menciptakanmu dan orang-orang yang sebelummu, agar kamu bertakwa." (QS. al-Baqarah, [2]: 21) ${ }^{78}$

Allah ciptakan manusia untuk beribadah kepada-Nya, sehingga semua aktivitas hidup adalah ibadah kepada Allah. Abdurrauf menulis:

Dan sibukkanlah dirimu dalam ibadah disertai sikap jujur dan ikhlas, dengan niat melaksanakan hak Tuhanmu, niscaya engkau termasuk ke dalam golongan orang-orang yang makrifat. Pengarang kitab al-Hikam mengatakan,"Kehendak ahli ma'rifat adalah benar-benar dalam beribadah dan melaksanakan hak-hak Tuhan". Allah Ta'āla berfirman, "Padahal mereka tidak disuruh kecuali agar menyembah Allah dengan memurnikan ketaatan kepada-Nya dalam menjalankan agamanya". Firman-Nya lagi, " Dan sembahlah Tuhanmu sampai datang kepadamu yang diyakini (ajal)". 79

Tujuan penciptaan manusia lainnya adalah sebagai khalifah di permukaan bumi ini untuk melaksanakan semua perintah-Nya. Abdurrauf mengutip firman Allah "Sesungguhnya Aku hendak menjadikan seorang khalifah di muka bumi" (QS. al-Baqarah [2]: 30). ${ }^{80}$

\footnotetext{
76Ibid,, h. 7-15.

${ }^{77}$ Abdurrauf, Bayān Tajalli, h. 7.

${ }^{78}$ Abdurrauf Singkel, Kifāyah al-Muhtājīn, h. 6.

${ }^{79}$ Abdurrauf Singkel, Tanbīh al-Māshi, Ms.B., h. 140, Ms.A., h. 57-58.

${ }^{80}$ Abdurrauf Singkel, Kifāyah al-Muhtājīn, h. 3.
} 
Konsep penghambaan diri dan melaksanakan tugas kekhalifahan di permukaan bumi ini merupakan landasan aksiologis terhadap pemikiran tasawuf Abdurrauf Singkel. Konsep ini menuntun seseorang untuk mampu memaknai kehidupannya sebagai pelaksanaan tugas penciptaan yang bermakna ibadah kepada Allah.

\section{Kesimpulan}

Abdurrauf Singkel merupakan tokoh sufi yang senantiasa menjadikan dalildali dalam al-Qur'an dan Hadis sebagai dasar dan sumber pemikiran tasawufnya dan menjadikannya sebagai landasan epistimologis dan normatif dalam membangun pemahaman dan pemikiran tasawufnya terutama dalam menjelaskan tauhid dan membincang tentang hakikat wujud, eksistensi Allah, hubungan ontologis antara Allah, manusia, dan alam. Akal tidak mampu mendapatkan atau mencapai hakikat wujud Allah karena akal itu adalah sesuatu yang diciptakan. Hanya berkat karunia Allah dalam bentuk dibukakan-Nya hati hamba-Nya dengan cahaya iman dan taufiq, manusia dapat mengetahui hakikat.

Pada aspek ontologis, walaupun tetap menggunakan istilah wahdāt alwujūd, Abdurrauf Singkel melakukan reinterpretasi terhadapnya. Reinterpretasi terhadap waḥdāt al-wujūd ini merupakan landasan utama pemikiran tasawuf Abdurrauf Singkel dalam menjelaskan hubungan ontologis antara Allah dan alam. Bagi Abdurrauf, alam tetap alam, dan khaliq tetap khaliq. Wujud itu hannya satu yaitu Allah, Sedangkan semua yang selain daripada Allah adalah sesuatu yang keberadaannya bergantung kepada adanya Allah Swt, atau seumpama bayangan atau bahkan cuma bayangan dari bayangan Allah Swt. Alam tercipta melalui proses pemancaran ( $a l-f a ' i d$, emanasi) melalui tujuh martabat. (Ahādiyah, waḥdah, wāhidiyyah, 'alām arwah, 'alām mithāl, 'alām ajsām 'alām insān.

Pada aspek aksiologis, pemikiran tasawuf Abdurrauf Singkel dilandasi dengan prinsip ibadah. Sebagai khalifah Allah di permukaan bumi, manusia dituntut untuk berniat melaksanakan hak Tuhan dan melaksanakan semua perintah-Nya serta menyibukkan diri dalam ibadah disertai sikap jujur dan ikhlas, memilih mati ikhtiyari dengan memfānakan diri melalui dzikir لااله الاله sehingga terbangun kondisi mental yang mampu memandang tiada yang hidup, tiada yang tahu, tiada yang kuasa, tiada yang berkehendak, tiada yang mendengar, tiada yang melihat, dan tiada yang berkata-kata pada hakikatnya selain dari pada Allah.] 


\section{DAFTAR PUSTAKA}

Abdullah, M. Shagir, Khasanah Karya Pusaka Asia Tenggara, Kuala Lumpur: Khazanah Fathaniyah, Jilid I, 1991.

Achmadi, Ideologi Pendidikan Islam Paradigma Humanisme Teosentris, Yogyakarta: Pustaka Pelajar, 2005.

'Arabi, Ibn, Fusūs al-Hikām, Penj: R.W.J Austin, Yogyakarta: Islamika, 2004.

al-Attas, Muhammad Naquib , The Mysticism of Hamzah Fansuri, Kuala Lumpur: University of Malaya Press. 1970.

al-Biqāâî, Ibrāhīm bin 'Umar bin Hasan al-Ribāth bin 'Alī bin Abī Bakar, w 885 H, Mashāild al-Nazhari li al-Asyrāf'ala Maqāshidi al-Siwari, Riyadh: Maktabah al-Ma'arif, 1987 M/ $1408 \mathrm{H}$.

Anwar, Rosihan, Ilmu Tashawwuf, Bandung: Pustaka Setia. 2000.

Australian National University, 1965.

Azra, Azyumardi, Jaringan Ulama Timur Tengah dan Kepulauan Nusantara Abad XVII dan XVIII, Bandung: Penerbit Mizan, 1994.

al-Damsyiqī, Ismāīl bin Muhammad bin 'Abdu al-Hādi al-Jarāhī al-'Ajilūnī , Kasyf al-Khafa', Kairo, Maktabah al-Qudsi, 1351.

Fang, Liaw Yock, Sejarah Kesusastraan Melayu Klasik, Singapura: Pustaka Nasional PTE LTD, 1982.

al-Faruqi, Ismail Raji, Islamisasi Pengetahuan,Terj: Anas Wahyudin, (Bandung: Pustaka, 1982.

Fathurrahman, Oman, Tanbīh al-Māshī; Menyoal Waḥdātul Wujūd, Kasus Abdurrahman Singkel di Aceh Abad 17, Jakarta: Mizan, 1999.

Fathurrahman, Oman, Tarekat Shațāiiyyah di Minangkabau, Jakarta: PPIM UIN Jakarta, 2008.

al-Fidā', Ismāîl Haqqī bin Mushthafā al-Istanbūlī al-Hanāfi al-Khulwatī al-Maulā Abū w. 1127, Rūh al-Bayān, Beirut: Dar al-Fikr, t.th.

al-Hindi, Muhammad 'Abd al-Hayyi bin Muhammad 'Abd al-Halīm al-Anshāri alLaknawi, w. 1304 H, al-Athār al-Marfü'ah fi al-Akhbāri al-Mawḍūa'ah,

JURNAL THEOLOGIA — Volume 28, Nomor 2, Desember 2017 
Muhaqqiq: Zaghluli, Muhammad al-Sa'id Basiyūnī, Baghdad: Maktabah alSyarq al-Jadīd, t.th.

Hidayat, Komaruddin. Memahami Bahasa Agama: Sebuah Kajian Hermeneutika, Jakarta: Paramadina, 1996.

Ismael, Ilma Nugrahani, 'Awārif al-Ma'ārif: Sebauah Buku Daras Klasik Tashawwuf Jakarta: Pustaka Hidayah, 1998.

Johns, A.H., The Gift Addressed to the Spiritof the Prophet, Canberra: Published by Australian National University, 1965.

Nasution, Harun, dkk. Ensiklopedi Islam Indonesia, Jakarta: Djambatan, 1992

Nasution, Harun, Falsafah dan Mistisisme dalam Islam, Jakarta: Bulan Bintang, 1993.

Nata, Abuddin, Pendidikan dalam Perspektif al-Qur'ān, Jakarta: UIN Jakarta Press, 2005.

Rinkes, D.A, Abdoeraoef van Singkel' Bijdrage tot de kennis van de mystiek op Sumatra en Java, Heerenven: Hepkema, 1909, hlm.25, Hurgronje, Jilid II, 1997.

Rivauzi, Ahmad, "Pemikiran Abdurrauf Singkel tentang Pendidikan dan Implikasinya pada Pondok Pesantren Nurul Yaqin Ringan-Ringan Pakandangan Padang Pariaman", Disertasi, PPs IAIN Imam Bonjol, Padang, 2014.

Rivauzi, Ahmad, Pendidikan Berbasis Spiritual; Pemikiran Pendidikan Abdurrauf Singkel dalam Kitab Tanbih al-Masyi, Padang: Jasa Surya, 2013.

Singkel, Abdurrauf, Bayān Tajalli, t.th.

Singkel, Abdurrauf, Kifāyah al-Muhtājīn, t.th.

Singkel, Abdurrauf, Tanbih al-Masi, Ms.A. t.th.

Singkel, Abdurrauf, Tanbih al-Masi, Ms.B, t.th.

Singkel, Abdurrauf, Daqā'iq al-Hurūf, t.th.

Stokes, Jane, How To Do Media and Cultural Studies; Panduan untuk Melaksanakan Penelitian dalam Kajian Media dan Budaya, Penj: Santi Ari Astuti, Yogyakarta: Bentang, 2006. 
Sutrisno, Hadi, Metodologi Research, Yokyakarta: Rake Sarasin, t.th.

Suyanto, Bagong dan Sutinah, Metode Penelitian Sosial; Berbagai Alternatif Pendekatan, Jakarta: Kencana, 2005.

Taftazani, Abu al-Wafa' al-Ghanimi, Terj: Sufi dari Zaman ke Zama , dari Madkhal ilā at-Tashawwuf al-Islāmi, oleh Ahmad Rofi Usmani. Bandung: Pustaka, 1985.

Tailor, Steven J. dan Robert Bogdan, Intoduction to Qualitative Research Methods; thlme Search for Meaning. New York: Wiley \&Sons.Inc, 1984

Voorhoeve, P., Bayān Tajalli; Bahan-bahan untuk Mengadakan Penyelidikan Lebih Mendalam tentang Abdurrauf Singkel. Alih Bahasa: Aboe Bakar, Banda Aceh: Pusat Dokumentasi dan Informasi Aceh, 1980.

Yunus, Mahmud, Kamus Arab Indonesia, Jakarta: Hidakarya Agung, 1990. 
328 JURNAL THEOLOGIA — Volume 28, Nomor 2, Desember 2017 